\title{
Badanie skuteczności warstwy przeciwkorozyjnej wytworzonej przez olej ochronny o niskiej lepkości w warunkach polowych
}

\section{Field examination of the effectiveness of the corrosion layer formed by the protective oil of low viscosity}

Jarosław Frydrych, Monika Ziółkowska

Sieć Badawcza Łukasiewicz - Przemysłowy Instytut Motoryzacji

\begin{abstract}
STRESZCZENIE: Zjawisko korozji atmosferycznej metali przynosi znaczne straty ekonomiczne w gospodarce większości krajów rozwiniętych. Chcąc je zmniejszyć, opracowano wiele metod ochrony powierzchni metali przed korozją, wykorzystujących zjawiska fizyczne, jak i reakcje chemiczne. Jedną z metod opartych na zjawisku fizycznej ochrony jest ochrona czasowa metali środkami smarowymi, tj. smarami plastycznymi oraz olejami smarowymi - ochronnymi. Smary plastyczne charakteryzują się bardzo dużą lepkością kinematyczną i wytwarzają szczelne i grube warstwy ochronne na powierzchni metali. Oleje ochronne przeznaczone do ochrony czasowej mają za zadanie utworzyć na powierzchni metalu szczelną, cienką, dobrze przylegającą warstwę ochronną. Ochrona czasowa metali przed korozją olejem ochronnym polega na pokryciu powierzchni metalu łatwo usuwalnymi środkami smarowymi, mającymi za zadanie wytworzenie szczelnej warstwy ochronnej oddzielającej powierzchnię chronionego metalu od niekorzystnego wpływu warunków atmosferycznych. Ochronę czasową metali stosuje się również do zabezpieczenia przed korozją półproduktów pomiędzy etapami produkcyjnymi, a w przypadku gotowych wyrobów - np. podczas magazynowania i transportu. Jedną z najważniejszych cech olejów ochronnych jest wytwarzanie na powierzchni metalu cienkiej warstwy ochronnej mającej za zadanie oddzielenie powierzchni metalu od otaczającego powietrza. Taka warstwa wytwarzana jest przez oleje ochronne o niskiej lepkości kinematycznej. Ze względu na brak jakichkolwiek wymagań dotyczących badań eksploatacyjnych dla olejów ochronnych w warunkach rzeczywistych - podjęto próbę opracowania takiej metodyki i zweryfikowania jej poprzez przeprowadzenie badania w warunkach polowych. W artykule opisana została metoda badania skuteczności ochrony metali przed korozją w warunkach polowych. Przedstawiono sposób przygotowania powierzchni wybranych elementów do ochrony przed korozją i sposób nałożenia warstwy ochronnej na płytki metali o kształcie prostym i o skomplikowanym kształcie powierzchni. Zamieszczono opis stanowiska badawczego, jak i metody wyboru miejsc ekspozycji. Przedstawione zostały wyniki przeprowadzonego badania. Uzyskane wyniki badań mają charakter aplikacyjny.
\end{abstract}

Słowa kluczowe: korozja, olej ochronny, czasowa ochrona, lepkość kinematyczna, badania polowe.

ABSTRACT: The phenomenon of atmospheric corrosion of metals causes significant economic losses in the economy of most developed countries. In order to reduce them, many methods have been developed that use physical phenomena and chemical reactions to protect metal surfaces against corrosion. One of the methods that use the phenomenon of physical protection is temporary protection of metals with lubricants, i.e. plastic greases and lubricating-protective oils. Plastic greases are characterized by a very high kinematic viscosity and create tight and thick protective layers on the surface of metals. Protective oils intended for temporary protection are designed to create a tight, thin, well-adhering protective layer on the metal surface. Temporary protection of metals against corrosion with protective oil consists in covering the metal surface with easily removable lubricants, whose task is to create a tight protective layer separating the surface of the protected metal from the adverse effects of weather conditions. Temporary metal protection is also used in the case of corrosion protection of intermediates between production stages, and in the case of finished products, e.g. during storage and transport. One of the most important features of protective oils is the formation of a thin protective layer on the metal surface to separate the metal surface from the surrounding air. This protective layer is produced by protective oils of low kinematic viscosity. Due to the lack of any requirements for operational tests for protective oils in real conditions, an attempt was made to develop such a methodology and verify it by conducting a field test. The article describes a method of testing the effectiveness of metal protection against corrosion in field conditions. The method of preparing the surface of selected elements for corrosion protection and the method of applying a protective layer on metal plates of a simple shape and with a complex surface shape are described. The description of the test stand as well as the method of selecting the places of exhibition are included. The results of the conducted study are presented. The obtained test results are of an application nature.

Key words: corrosion, protective oil, temporary protection, kinematic viscosity, field tests.

Autor do korespondencji: J. Frydrych, e-mail: jaroslaw.frydrych@pimot.lukasiewicz.gov.pl

Artykuł nadesłano do Redakcji: 04.06.2020 r. Zatwierdzono do druku: 25.12.2020 r. 


\section{Wprowadzenie}

Procesy niszczenia metali związane z korozją przynoszą duże straty dla gospodarki wielu krajów. W celu zmniejszenia tych strat w zależności od zastosowanego metalu, jak i jego dalszego wykorzystania w przemyśle stosuje się różne formy zabezpieczenia powierzchni przed niekorzystnym wpływem środowiska (Surowska, 2002).

Jedną z form zabezpieczenia powierzchni metalu przed niepożądanym oddziaływaniem warunków atmosferycznych jest ochrona czasowa metali (Tate i Beale, 2010; Żabicki, 2012). Polega ona na zabezpieczeniu powierzchni produktu lub półproduktu wykonanego z metalu łatwo usuwalnymi środkami mającymi za zadanie odizolowanie powierzchni od niekorzystnego wpływu warunków atmosferycznych. Ochronę czasową metali stosuje się w przypadku półproduktów pomiędzy etapami produkcyjnymi, a w przypadku wyrobów gotowych - np. podczas magazynowania i transportu (Baszkiewicz i Kamiński, 2006).

Najczęściej stosowaną ochroną czasową metali przed korozją jest ochrona wytworzona przez środki smarowe, tj. smary plastyczne i oleje ochronne (Steinmec et al., 1984; Surowska, 2002, Patent PL 195208, Patent PL 201820, Patent PL 133639). Smary plastyczne wytwarzają szczelne i grube warstwy ochronne na powierzchni metali, natomiast oleje ochronne mają za zadanie pozostawić na powierzchni metalu szczelną, cienką, dobrze przylegającą warstwę ochronną. Utworzona na powierzchni metalu warstwa ochronna nie może powodować sklejania się przechowywanych elementów, np. zabezpieczone olejem ochronnym stosy łożysk tocznych używane w automatycznych procesach montażu muszą dać się w łatwy sposób rozdzielić. Zabezpieczone olejem ochronnym elementy w celu zwiększenia ochrony pakowane są w specjalny papier pergaminowy (Patent PL 134565) dla zabezpieczania przed wpływem fizycznego oddziaływania środowiska atmosferycznego, np. zanieczyszczeń pyłami, kurzem lub przed przypadkowym uderzeniem.

Jedną z największych zalet zastosowania oleju ochronnego do czasowej ochrony powierzchni metalu jest łatwość usuwania warstwy ochronnej przed następnym procesem technologicznym. W celu usunięcia tej warstwy zabezpieczoną powierzchnię metalu wystarczy przemyć rozpuszczalnikiem. Przemywanie najczęściej wykonywane jest poprzez zanurzenie chronionych elementów w rozpuszczalniku lub poprzez natrysk substancji myjącej, np. lekkich frakcji naftowych zawierających środki powierzchniowo czynne, inhibitory korozji, inhibitory utleniania, środki wypierające wodę, inne substancje powierzchniowo-aktywne (TOTAL Polska, 2003; Hunter i Paul, 2004). Środki ochrony czasowej przed korozją mają za zadanie chronić powierzchnię metalu przed utlenianiem przez ściśle określony czas, np. pomiędzy etapami technologicznymi w procesie produkcji (Zawadzki, 1962, 1969; Surowska, 2002; Zhang et al., 2018).

Po wyznaczonym czasie warstwa ochronna może ulegać degradacji, np. mogą zachodzić procesy starzenia oleju, co może powodować powstawanie związków chemicznych o kwaśnym charakterze, powodujące przyśpieszenie wystąpienia zjawiska korozji na powierzchni metalu.

Użytkownicy zabezpieczający półprodukty między procesami technologicznymi, jak i gotowe wyroby olejami ochronnymi sami doświadczalnie ustalają warunki ich magazynowania (temperaturę, wilgotność i dopuszczalny czas przechowywania).

Ze względu na brak normatywnych wymagań dotyczących badań eksploatacyjnych dla olejów do ochrony czasowej przed korozją atmosferyczną - podjęto próbę opracowania metodyki przeprowadzenia takich badań w warunkach polowych.

\section{Obiekt badań}

Obiektem badań był opracowany olej ochronny przeznaczony do czasowej ochrony metali przed korozją o bardzo niskiej lepkości kinematycznej w temperaturze $100^{\circ} \mathrm{C}$ (RJ.481.1.2018.1.RP).

Przed rozpoczęciem badań eksploatacyjnych przygotowano partię badawczą oleju ochronnego, zgodnie z opracowaną recepturą.

\section{Metodyka badań}

\section{Opracowanie metody przeprowadzenia badań eksploatacyjnych oleju ochronnego}

Metoda badania polegała na pokryciu, metodą zanurzeniową, wybranych metalowych płytek oraz metalowych elementów konstrukcyjnych o nieregularnych kształtach olejem ochronnym i przetrzymywaniu ich w zmiennych warunkach atmosferycznych na wolnym powietrzu w określonym czasie.

Po oczyszczeniu z zanieczyszczeń mechanicznych, jak i korozyjnych - płytki oraz elementy konstrukcyjne przed pokryciem olejem ochronnym zostały odtłuszczone i osuszone. Metoda nanoszenia środka smarowego na powierzchnię polegała na całkowitym zanurzeniu badanego elementu w oleju ochronnym i przetrzymaniu przez co najmniej 1 minutę. Następnie pokryte olejem ochronnym elementy zostały zawieszone na 24 godziny w celu obcieknięcia nadmiaru oleju i wyschnięcia warstwy ochronnej.

Wybrana metoda nanoszenia środka smarowego na powierzchnię jest bardzo dobrym i tanim sposobem jej zabezpieczenia, ponieważ olej wnika do wszystkich nierówności elementu, równomiernie ją pokrywając. 
Po 24 godzinach zabezpieczone elementy metalowe zostały umieszczone na stanowisku badawczym, tylko od góry zadaszonym, tak aby opady atmosferyczne nie uszkodziły wytworzonej warstwy ochronnej z powierzchni.

Poniżej przedstawiono stanowisko badawcze (rys. 1) do prowadzenia badań eksploatacyjnych oleju ochronnego w warunkach polowych.

Autorzy nie założyli kryterialnych warunków temperaturowych i wilgotnościowych prowadzenia testu, a jedynie czas prowadzenia testu został ustalony na $60 \mathrm{dni}$. Ze względu na bardzo korzystne warunki atmosferyczne panujące w czasie badania, w wyniku czego na wystawionych elementach nie powstała korozja, postanowiono wydłużyć czas testu o kolejne dwa miesiące.

Założenia do prowadzenia testu polowego:

- rozmieszczenie stanowisk badawczych z zabezpieczonymi elementami metalowymi w różnych miejscach na otwartej przestrzeni w warunkach polowych;

- obserwacja metalowych elementów co 7 dni w celu określenia czasu powstania zmian korozyjnych;

- czas trwania badania polowego: 60 dni (następnie wydłużony o 2 miesiące);

Po zakończeniu badania zabezpieczone elementy metalowe zostały umyte w rozpuszczalniku organicznym i poddane ocenie pod kątem zmian korozyjnych na powierzchni.

\section{Przeprowadzenie badania w warunkach polowych z zastosowaniem ustalonej metody badawczej}

Badanie polegało na pozostawieniu na wolnym terenie w warunkach polowych elementów metalowych zabezpieczonych olejem ochronnym i wystawieniu ich tym samym na działanie zmiennych warunków atmosferycznych. Zabezpieczone w opisany sposób elementy metalowe zostały umieszczone pod dachem w celu ochrony przed bezpośrednim działaniem opadów deszczu, które w sposób trwały mogłyby uszkodzić zabezpieczoną powierzchnię metali.

Zadaszone stanowisko badawcze umożliwiało umieszczenie na nim elementów konstrukcyjnych, jak i płytek wykonanych z różnych metali i stopów.

Na początku planowane było wystawienie elementów na bezpośrednie działanie warunków atmosferycznych przez 60 dni. Ze względu na brak widocznych śladów korozji na większości elementów postanowiono wydłużyć okres ekspozycji o dwa miesiące.

Po pierwszym okresie badawczym, tj. po 60 dniach (wrzesień i październik), nie zaobserwowano widocznych śladów korozji. Mogło to być spowodowane występowaniem w tym czasie wysokich temperatur, bardzo dużego nasłonecznienia i bardzo małych opadów deszczu. W drugim etapie badawczym nastąpiło już znaczne zróżnicowanie warunków atmosferycznych. Występowały duże dobowe różnice temperatur, opady deszczu oraz silne wiatry. Zdarzyły się opady śniegu.

Do badania wytypowane zostały elementy konstrukcyjne silnika samochodowego wykonane ze stali (wałek rozrządu i koła pasowe pochodzące z silnika samochodowego) oraz $\mathrm{z}$ aluminium (uchwyt panewki wałka rozrządu). Dodatkowo do badań eksploatacyjnych w warunkach rzeczywistych wybrane zostały płytki z następujących metali i ich stopów:

- aluminium o zawartości glinu do 99,5\%;

- miedzi o zawartości miedzi do $99,9 \%$;

- ołowiu o zawartości ołowiu do 99,9\%;

- mosiądzu, stopu miedzi i cynku, o zawartości do $40 \%$ cynku i $60 \%$ miedzi;

- stali C45 o zawartości węgla od $0,42 \%$ do $0,5 \%$;

- stali S235JR o zawartości węgla do 0,2\%.

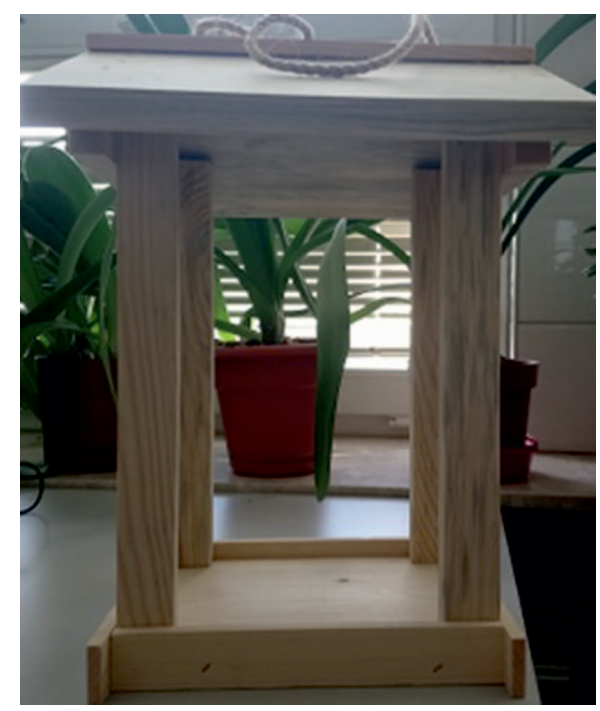

Rys. 1. Stanowisko do badań eksploatacyjnych oleju ochronnego w warunkach polowych

Fig. 1. Stand for operational testing of protective oil in field conditions

Materiały te znajdują powszechne zastosowanie w elementach konstrukcyjnych silnika samochodowego. Przykładowo ze stopów aluminium produkowane są kadłuby silników, głowice silnika, miski olejowe, wały napędowe oraz wahacze. Dzięki dobrym właściwościom przewodzącym elektryczność miedź jest stosowana do wytwarzania uzwojeń silników elektrycznych, alternatorów, rozruszników, cewek zapłonowych oraz przewodów elektrycznych. Jest też składnikiem stopów metali, np. mosiądzu, z którego wykonywane są rurki chłodnic i złącza elektryczne. Stale znajdują zastosowanie w produkcji m.in. korbowodów, wałków rozrządu i sworzni tłokowych. Każdy z wybranych metali i stopów wykazuje również inną odporność korozyjną. W przypadku stali na odporność 


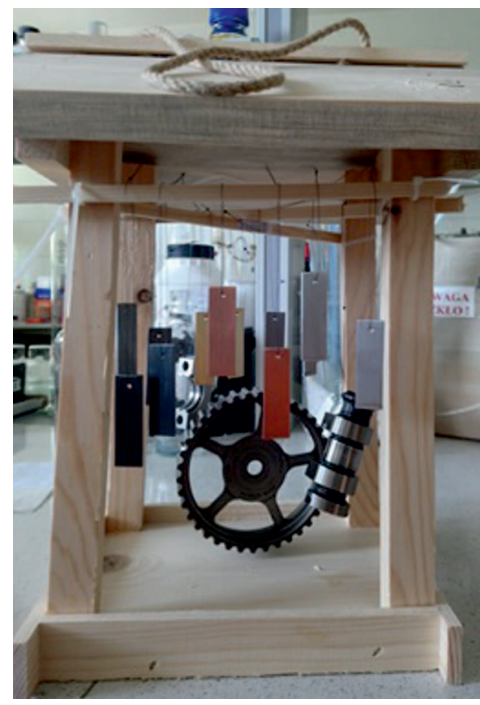

Rys. 2. Rozmieszczenie wytypowanych elementów na stanowisku badawczym

Fig. 2. Distribution of selected elements in the test stand

korozyjną wpływa jej skład chemiczny. Wyższa zawartość węgla pogarsza odporność na korozję (stal gatunku C45 szybciej ulega korozji niż stal S235JR).

Wybrane do badania elementy metalowe zostały zawieszone na specjalnie opracowanych zawieszkach obojętnych chemicznie dla chronionego metalu, w taki sposób, aby podczas ekspozycji zmniejszyć do minimum możliwość mechanicznego uszkodzenia powierzchni ochronnej.

Wytypowano 4 miejsca ustawienia stanowisk badawczych o zróżnicowanym działaniu warunków atmosferycznych:

- 1. stanowisko badawcze usytuowane na wolnym terenie na wysokości ponad 2,5 m;

- 2. stanowisko badawcze usytuowane na wolnym terenie na wysokości ponad 2,5 m w miejscu częściowo zacienionym;

- 3. stanowisko badawcze usytuowane w miejscu częściowo osłoniętym od wiatru i nasłonecznienia;

- 4. stanowisko badawcze usytuowane na wolnej przestrzeni na dachu budynku.

We wszystkich miejscach umieszczono taki sam pakiet chronionych elementów (rys. 2).

Na rysunku 3 pokazane zostały przygotowane przykładowe stanowiska badawcze.

\section{Przeprowadzenie badania}

Przed przystąpieniem do testu w warunkach polowych - wykonane zostały badania właściwości fizykochemicznych, jak i użytkowych w warunkach laboratoryjnych oleju ochronnego według wcześniej opracowanych założeń, w celu potwierdzenia wysokiej jakości oleju i sprawdzenia prawidłowego przygotowania partii produkcyjnej oleju. Uzyskane wyniki badania właściwości fizykochemicznych
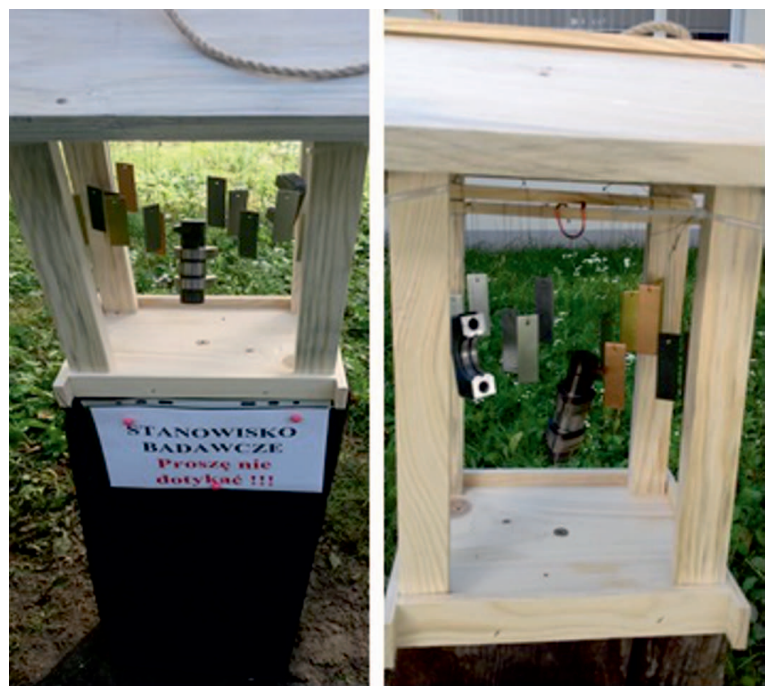

Rys. 3. Stanowisko badawcze usytuowane w warunkach polowych Fig. 3. Test stand situated in the field

pozwoliły potwierdzić, że olej ochronny został przygotowany zgodnie z wcześniej opracowanymi wytycznymi.

Wyniki badań zamieszczone zostały w tabeli 1.

Przygotowany do badań eksploatacyjnych olej ochronny charakteryzuje się niską lepkością kinematyczną w temperaturze $100^{\circ} \mathrm{C}$ oraz bardzo dobrymi właściwościami przeciwrdzewnymi i korozyjnymi.

Tabela 1. Właściwości fizykochemiczne oleju ochronnego

Table 1. Physical and chemical properties of protective oil

\begin{tabular}{|l|c|c|}
\hline \multicolumn{1}{|c|}{ Badane parametry } & $\begin{array}{c}\text { Jednostka } \\
\text { miary }\end{array}$ & $\begin{array}{c}\text { Olej } \\
\text { ochronny }\end{array}$ \\
\hline \hline $\begin{array}{l}\text { Lepkość kinematyczna } \\
- \text { w temp. } 40^{\circ} \mathrm{C} \\
-\mathrm{w} \text { temp. } 100^{\circ} \mathrm{C}\end{array}$ & $\mathrm{mm}^{2} / \mathrm{s}$ & $\begin{array}{l}8,544 \\
2,461\end{array}$ \\
\hline Wskaźnik lepkości & - & 111 \\
\hline Temperatura płynięcia & ${ }^{\circ} \mathrm{C}$ & -15 \\
\hline Temperatura zapłonu & ${ }^{\circ} \mathrm{C}$ & 168 \\
\hline Odczyn wyciągu wodnego & - & alkaliczny \\
\hline $\begin{array}{l}\text { Badanie działania korodującego na płytkach } \\
\text { z Cu, } 100^{\circ} \mathrm{C} / 3 \text { h }\end{array}$ & skala ASTM & $1 \mathrm{a}$ \\
\hline Pozostałość po spopieleniu & $\%(\mathrm{~m} / \mathrm{m})$ & 0,01 \\
\hline $\begin{array}{l}\text { Badanie właściwości przeciwkorozyjnych na } \\
\text { trzpieniu stalowym z wodą destylowaną }\end{array}$ & - & $\mathrm{A}$ \\
\hline Zawartość stałych ciał obcych & $\%$ & nie zawiera \\
\hline Zawartość wody & $\%$ & nie zawiera \\
\hline Gęstość w temperaturze $20^{\circ} \mathrm{C}$ & $\mathrm{kg} / \mathrm{dm}{ }^{3}$ & 0,883 \\
\hline Barwa wg Lovibonda & - & 2,5 \\
\hline $\begin{array}{l}\text { Grubość warstwy wytworzonej przez środek } \\
\text { ochronny }\end{array}$ & $\mu \mathrm{m}$ & 5 \\
\hline $\begin{array}{l}\text { Badanie własności przeciwkorozyjnych w ko- } \\
\text { morze wilgotnościowej: }\end{array}$ & liczba cykli & 14 \\
\hline
\end{tabular}

* 1 cykl $=24$ godziny 
Badanie właściwości przeciwrdzewnych

Zasada metody badania właściwości przeciwrdzewnych na miedzi zgodnie z normą PN EN ISO 2160:2004 polega na zanurzeniu w próbce oleju wypolerowanej płytki miedzianej i ogrzewanie jej w czasie 3 godzin w temperaturze $100^{\circ} \mathrm{C}$. Po zakończeniu badania próbkę przemyto lekkim rozpuszczalnikiem węglowodorowym niezawierającym siarki i niepowodującym zmiany barwy badanej płytki, i ocenie barwy porównując z wzorcami korozji.

\section{Badanie właściwości przeciwkorozyjnych}

Badanie właściwości przeciwkorozyjnych na trzpieniach stalowych wykonywane było zgodnie z normą PN-81/C-04082. Badanie polega na wytworzeniu emulsji olejowo-wodnej w temperaturze $60^{\circ} \mathrm{C}$, w której zanurzony jest całkowicie trzpień stalowy. Test trwa 24 godziny. Wynikiem badania właściwości przeciwkorozyjnych jest stopień skorodowania powierzchni trzpienia stalowego.

Ocena stopnia korozji wykonywana była według następującej skali:

$\begin{array}{ll}\text { A } & \text { Brak korozji } \\ \text { B++ } & <0,1 \% \\ \text { B+ } & <5 \% \\ \text { B } & 5-25 \% \\ \text { C } & 25-50 \% \\ \text { D } & 50-75 \% \\ \text { E } & 75-100 \%\end{array}$

Badanie właściwości przeciwkorozyjnych w komorze

wilgotnościowej

Badania właściwości przeciwkorozyjnych w komorze wilgotnościowej zostały przeprowadzone zgodnie z normą PN-75/C-04154.

Metoda badania polega na umieszczeniu stalowych płytek pokrytych badanym olejem w komorze wilgotnościowej (rys. 4) i po upływie określonego czasu - na określeniu zmian powstałych na powierzchni.

Do badania wykorzystywane są płytki stalowe o ściśle określonych wymiarach i odpowiednio przygotowanej powierzchni, którą pokrywa się badanym środkiem smarowym, zawieszane na specjalnych haczykach niewywołujących reakcji z płytką stalową. W celu wytworzenia atmosfery o dużej wilgotności komorę wilgotnościową wypełnia się wodą i przez specjalne dyfuzory umieszczone w wodzie przepuszcza powietrze o natężeniu przepływu 875 l/h. Badanie prowadzone jest w temperaturze $50^{\circ} \mathrm{C}$ i stałej wilgotności względnej $90-100 \%$.

W tych warunkach płytki są przetrzymywane do pierwszych śladów korozji - nie więcej niż 3 punktów korozyjnych o średnicy nie większej niż $1 \mathrm{~mm}$. Czas badania w komorze wilgotnościowej określa się w cyklach (jeden cykl to 24 godziny).
Po każdym cyklu prowadzono obserwację płytek i oceniano je pod kątem powstania śladów korozji.

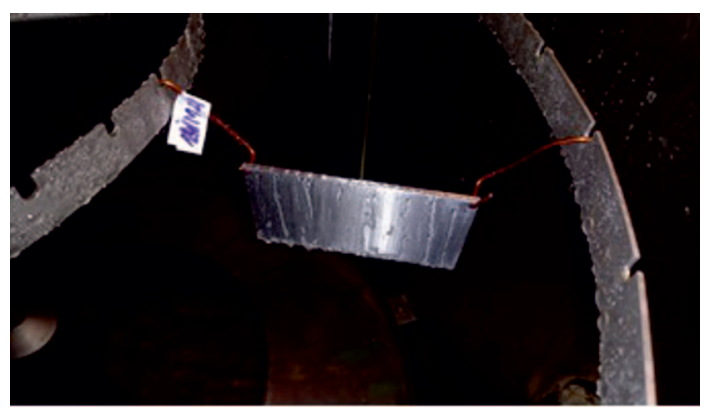

Rys. 4. Komora wilgotnościowa

Fig. 4. Moisture chamber

Kolejnym ważnym kryterium dla badanego oleju ochronnego było uzyskanie cienkiej warstwy ochronnej. Poniżej przedstawiona została metoda obliczenia grubości wytworzonej warstwy ochronnej.

Grubość warstwy oleju ochronnego wyznaczono metodą wagową. Metoda polega na dokładnym określeniu powierzchni pokrywanej środkiem smarowym i oznaczeniu różnicy masy pomiędzy elementem bez środka smarowego i pokrytym olejem ochronnym. Następnie ze wzoru wylicza się objętość naniesionego środka smarowego (1).

$$
d=\frac{m}{V}
$$

gdzie:

$d$ - gęstość,

$m$ - masa,

$V$ - objętość.

Znając całkowitą powierzchnię pokrywanego elementu, oblicza się grubość warstwy środka smarowego.

W analizowanym przypadku grubość warstwy oleju ochronnego wynosiła $5 \mu \mathrm{m}$.

\section{Wyniki badań}

\section{Przygotowanie elementów do badań polowych}

(Frydrych, 2019)

Elementy konstrukcyjne oraz wybrane płytki metali przeznaczone do badania polowego zostały dokładnie oczyszczone ze wszystkich zanieczyszczeń powierzchni i środków korozji. Oczyszczone elementy zostały następnie przemyte rozpuszczalnikiem organicznym $\mathrm{w}$ celu pozbycia się $\mathrm{z}$ ich powierzchni tłustych zanieczyszczeń. Po umyciu elementy zostały osuszone. Po osuszeniu ponownie przeprowadzono kontrolę organoleptyczną wybranych losowo elementów w celu sprawdzenia, czy podczas procesów przygotowawczych nie została uszkodzona ich powierzchnia. 
Po umyciu i osuszeniu wszystkie elementy zostały pokryte olejem ochronnym metodą zanurzeniową.

Wybrana do pokrycia elementów olejem ochronnym metoda zanurzeniowa gwarantuje bardzo dokładne pokrycie całej ich powierzchni. Umożliwia ona dokładne wniknięcie środka smarowego w najbardziej skomplikowane nierówności powierzchni i równomierne jego naniesienie (rys. 5).

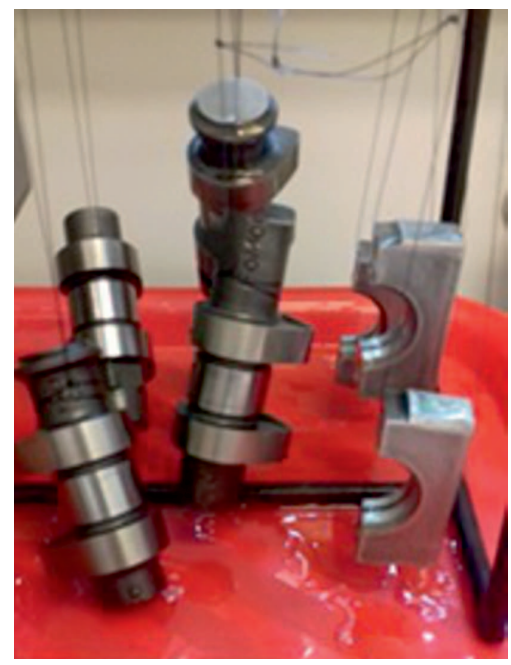

Rys. 5. Przykładowe elementy pokryte środkiem do ochrony czasowej

Fig. 5. Examples of elements covered with a temporary protection agent

Pokryte olejem ochronnym elementy metalowe wystawione zostały na działanie warunków atmosferycznych na początku września. Badanie zakończone zostało po 120 dniach.

Przez pierwsze 60 dni na żadnym stanowisku badawczym nie zaobserwowano zmian korozyjnych na powierzchni wystawionych płytek miedzi, mosiądzu, aluminium, ołowiu, stali C-45 i stali S235JR oraz aluminiowych uchwytów panewki, jak i kół. Nieznaczne ślady korozji pojawiły się na krzywkach wałka rozrządu umieszczonego na stanowisku ustawionym na wolnym nieosłoniętym terenie (rys. 6).

Jak już wspomniano, na początku planowano wystawienie elementów na bezpośrednie działanie warunków atmosferycznych na 60 dni. Ze względu na brak widocznych śladów korozji na płytkach metalowych, jak i powstanie nieznacznych śladów korozji na krzywce wałka rozrządu postanowiono pozostawić zabezpieczone metale na kolejne 60 dni.

W pierwszym okresie badawczym (wrzesień i październik) występowały bardzo sprzyjające warunki atmosferyczne do prowadzenia badań polowych (wysokie temperatury, bardzo duże nasłonecznienie, bardzo niska wilgotność powietrza i mało opadów deszczu). Drugi etap badania przypadał na miesiące listopad i grudzień. Wtedy nastąpiło znaczne zróżnicowanie warunków atmosferycznych, występowały duże dobowe różnice temperatur, wzrosła wilgotność powietrza, występowały opady deszczu oraz silne wiatry. Zdarzyły się również opady śniegu.

Po kolejnym okresie badawczym widoczne były zmiany na powierzchniach wszystkich elementów na wszystkich stanowiskach (rys. 7).
Wszystkie elementy po 120 dniach ekspozycji zostały umyte $\mathrm{w}$ rozpuszczalniku organicznym w celu usunięcia pozostałości oleju ochronnego i zanieczyszczeń pokrywających powierzchnię w sposób fizyczny, np. pyłu, kurzu (rys. 8).

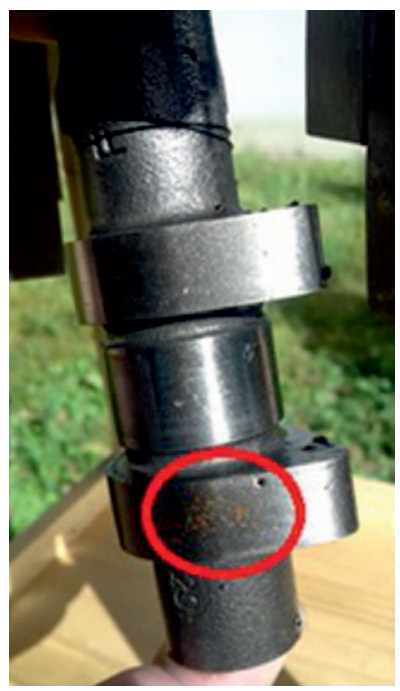

Rys. 6. Ślady korozji widoczne na wałku rozrządu po 60 dniach ekspozycji

Fig. 6. Traces of corrosion visible on the camshaft after 60 days of exposure

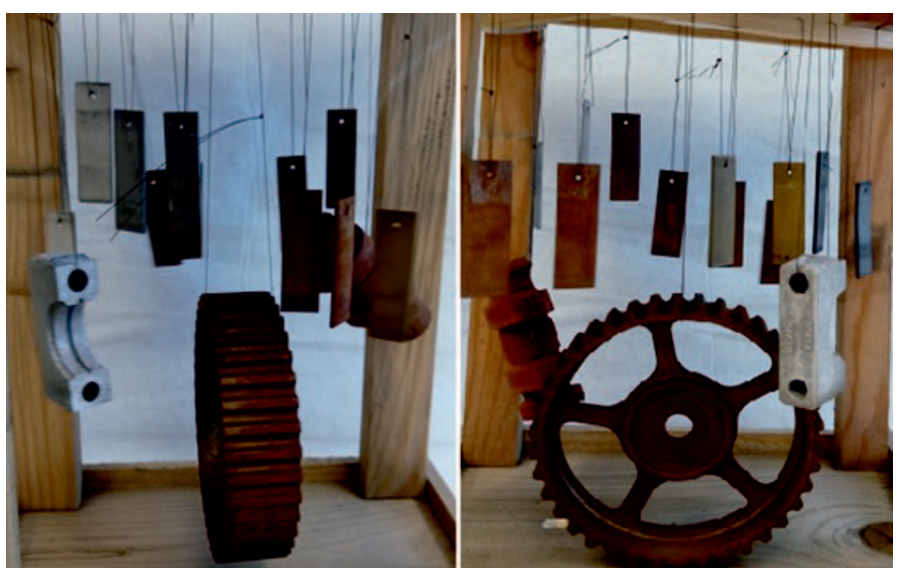

Rys. 7. Wygląd elementów na przykładowych dwóch stanowiskach po 120 dniach ekspozycji

Fig. 7. The appearance of elements in the example two stands after 120 days of exposure

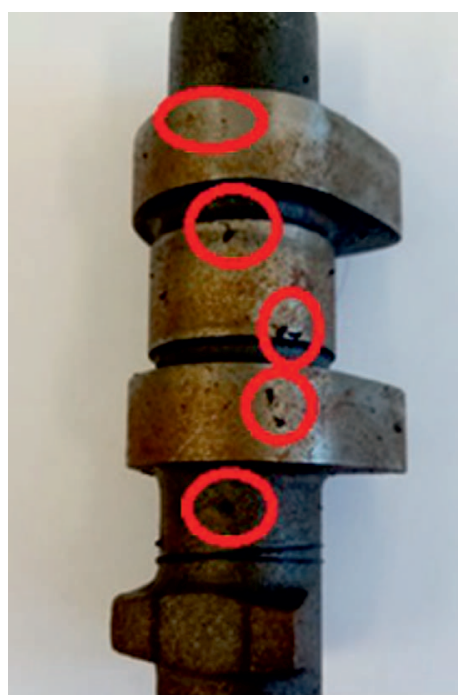

Rys. 8. Zanieczyszczenia na powierzchni metali

Fig. 8. Contamination on the surface of metals 
Stal C-45

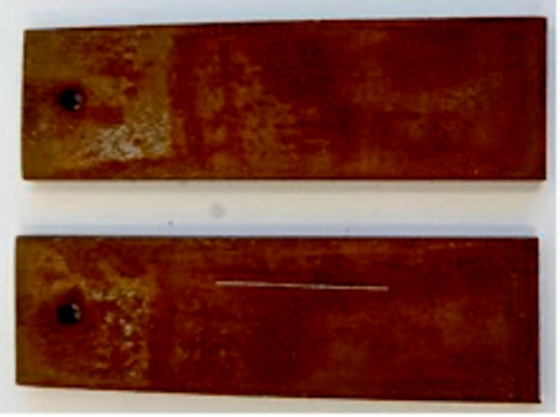

Rys. 9. Ślady korozji na powierzchni płytek stalowych

Fig. 9. Traces of corrosion on the surface of steel plates

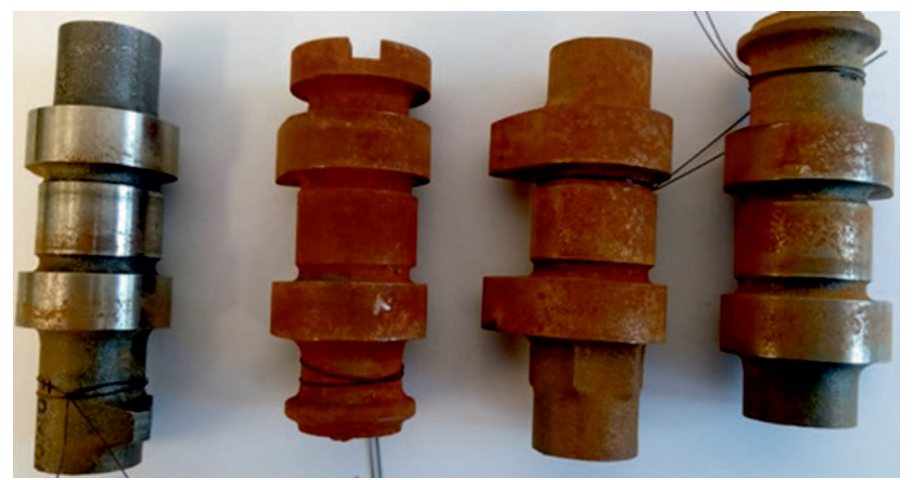

Rys. 10. Elementy wałka rozrządu silnika po ekspozycji

Fig. 10. Components of the engine camshaft after exposure

Po umyciu wszystkie elementy poddane zostały ocenie wizualnej. Na wszystkich płytkach stalowych widoczne były ślady korozji. Na rysunku 9 przedstawiono przykładowe płytki ze stali C-45 i stali zbiornikowej S235JR.

Większą odporność na korozję ma stal zbiornikowa S235JR, charakteryzująca się mniejszą zawartością węgla.

Im większa zawartość węgla w stali, tym stal jest mniej odporna na korozję. Przeprowadzone badania potwierdzają tę hipotezę.

Jak widać na rysunku 9, stal C-45 jest o wiele bardziej skorodowana niż stal S235JR.

Na rysunku 10 przedstawione zostały skorodowane wałki rozrządu silnika. Wszystkie cztery elementy wystawione były na działanie warunków atmosferycznych, jednak miejsce ustawienia stanowiska badawczego miało wpływ na stopień skorodowania powierzchni, co zostało bardzo dobrze ukazane na rysunku 10 .

Części wałka rozrządu znajdujące się z lewej i prawej strony
S235JR

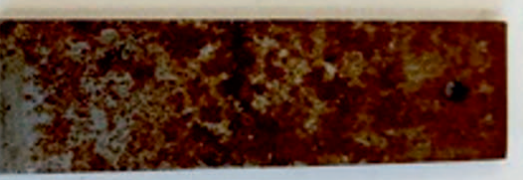

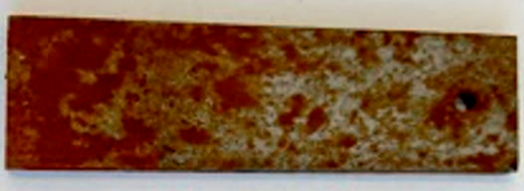

pochodzą ze stanowisk osłoniętych od wiatru i pyłów.

Powierzchnia wewnętrzna, jak i zęby kół pasowych wystawionych na działanie warunków atmosferycznych zostały pokryte rdzawym osadem (rys. 11).

Wystawione na działanie warunków atmosferycznych płytki po 120 dniach prowadzenia badań polowych pokryte zostały produktami utlenienia powierzchni, pyłem i kurzem. Wszystkie elementy po zakończeniu badania zostały dokładnie umyte w rozpuszczalnikach organicznych w celu usunięcia produktów zanieczyszczeń fizycznych (pyły, kurz).

Na rysunku 12 przedstawiony został wygląd wszystkich elementów wystawionych na wpływ warunków atmosferycznych.

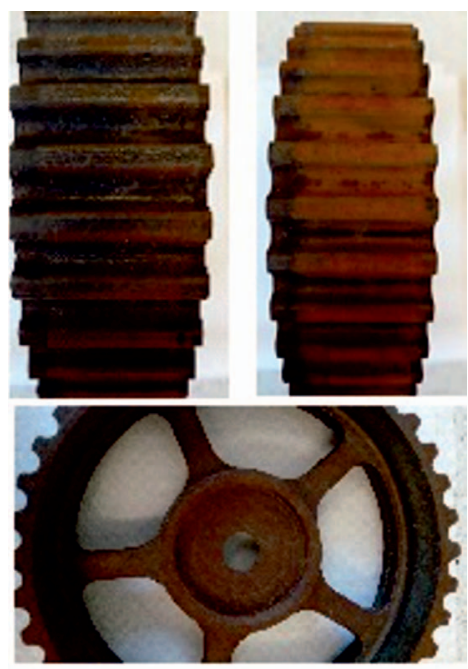

Rys. 11. Widok skorodowanych powierzchni kół pasowych

Fig. 11. View of the corroded surfaces of pulleys

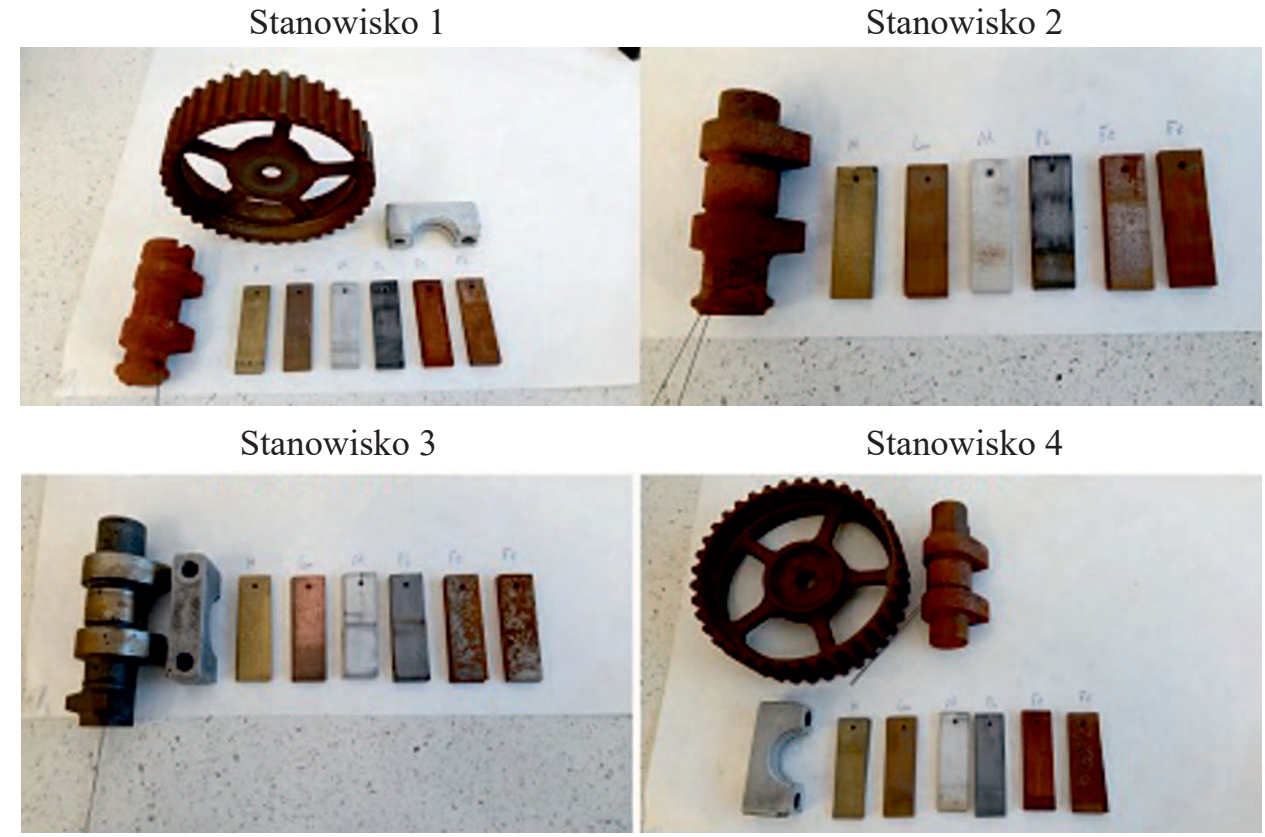

Rys. 12. Widok wszystkich elementów wystawionych na działanie warunków atmosferycznych Fig. 12. View of all elements exposed to weather conditions 
Wszystkie elementy powierzchniowo pokryte są tlenkami metali. W przypadku miedzi, mosiądzu i ołowiu utworzona warstwa tlenków stanowi warstwę ochronną i zabezpieczającą powierzchnię metalu przed szkodliwym działaniem warunków atmosferycznych. W przypadku aluminium widoczne są wżery białego tlenku glinu, na elementach stalowych widoczne jest całkowite pokrycie powierzchni brunatnym osadem tlenków żelaza, które stanowią trwałe korozyjne uszkodzenie powierzchni metalu.

\section{Podsumowanie}

Badany olej ochronny ma bardzo dobre właściwości kryjące i ochronne, charakteryzuje się bardzo dobrą płynnością, co przyczynia się do powstawania szczelnej, cienkiej i dobrze przylegającej do powierzchni metalu warstwy ochronnej.

Na podstawie przeprowadzonych badań w warunkach polowych można stwierdzić, że opracowany olej ochronny w pierwszym etapie bardzo dobrze zabezpieczał powierzchnię wszystkich metali przed niekorzystnym działaniem warunków atmosferycznych. W drugim etapie badań zmienność warunków atmosferycznych, jak i silne wiatry, które powodowały duże pylenie kurzu i piachu, doprowadzały do uszkodzenia warstwy ochronnej, odsłaniając powierzchnię - w przypadku elementów stalowych powstawała korozja, a w przypadku metali kolorowych, tj. miedzi, ołowiu i stopu mosiądzu, na odsłoniętej powierzchni powstawała szczelna warstwa tlenków metali (nastąpiła pasywacja na powierzchni metali, tworząc naturalną ochronę przeciwkorozyjną), które chroniły przed niekorzystnym działaniem warunków atmosferycznych.

W przypadku aluminium na powierzchni utworzyły się białe tlenki glinu, które nie stanowią ochrony powierzchni metalu przed dalszym działaniem czynników atmosferycznych.

\section{Wnioski}

Opracowany olej ochronny do czasowego zabezpieczania powierzchni metali przed korozją w sposób skuteczny ochronił powierzchnię wszystkich elementów wystawionych na ekspozycję działania warunków atmosferycznych w pierwszym okresie badawczym.

Opracowana metoda badania właściwości ochronnych metali przed korozją w warunkach polowych jest bardzo rygorystyczną metodą badawczą, niemającą odniesienia do warunków przechowywania elementów chronionych stosowanych w wymienionych wcześniej zakładach produkcyjnych. Otrzymane zadowalające wyniki badania polowego, szczególnie w pierwszym okresie badawczym, pozwalają stwierdzić, że opracowany olej ochronny będzie bardzo dobrze spełniał swoją rolę ochronną w magazynach o ściśle ustalonych i kontrolowanych warunkach atmosferycznych.

\section{Literatura}

Baszkiewicz J., Kamiński M., 2006. Korozja materiałów. OWPW, Warszawa: 9-13, 152-153.

Frydrych J., 2019. Badanie oleju ochronnego o niskiej lepkości w warunkach polowych. 10 Międzynarodowa Konferencja NaukowoTechniczna Środki Smarowe 2019.

Hunter L.R., Paul W.F., 2004. Cleaning of precision space assemblies. Metal Finishing, 102: 50-54.

Steinmec F., Łapa M., Szczurek T., 1984. Rozwój krajowych środków ochrony czasowej metali. Akorinol i Akorin. Konferencja Koninki.

Surowska B., 2002. Wybrane zagadnienia z korozji i ochrony przed korozją. Wydawnictwo Politechniki Lubelskiej, Lublin: 75-112.

Tate T.N., Beale E.W., 2010. Temporary Protectives. [W:] Cottis B., Graham M., Lindsay R. et al. (eds.). Shreir's Corrosion. Elsevier, 4: $2678-2682$.

TOTAL Polska, 2003. Przemysłowe środki smarne. TOTAL Polska Sp. z o.o., Warszawa: rozdziały 16 i 20.

Zawadzki J., 1962. Konserwacja i opakowania wyrobów metalowych. WNT, Warszawa: 86-123, 126-155.

Zawadzki J., 1969. Ochrona czasowa metali. WNT, Warszawa: 114-136. Zhang F., Ju P., Pan M., Zhang D., Huang Y., Li G., Li X., 2018. Selfhealing mechanisms in smart protective coatings. Corrosion Science, 144: 74-88. DOI: 10.1016/j.corsci.2018.08.005.

Żabicki D., 2012. Czasowa ochrona przed korozją. Magazyn Przemystowy. $<$ https://www.magazynprzemyslowy.pl/produkcja/Czasowa-ochronaprzed-korozja,2774,1> (dostęp: 28.09.2018).

\section{Patenty i normy}

Patent PL 133639 Środek do ochrony czasowej metali przed korozją, 1985.

Patent PL 134565 Sposób wytwarzania suchopowłokowego środka do ochrony czasowej metali przed korozją, 1983.

Patent PL 195208 Olej ochronny, 2001.

Patent PL 201820 Olej przekładniowo-ochronny i hydrauliczno-ochronny, 2003.

PN-EN ISO 2160:2004 Petroleum products - Corrosiveness to copper - Copper strip test.

PN-75/C-04154 Badanie własności przeciwkorozyjnych ciekłych środków ochrony czasowej metali w wilgotnej atmosferze.

PN-81/C-04082 Przetwory naftowe. Badanie własności przeciwkorozyjnych olejów mineralnych.

RJ.481.1.2018.1.RP Zgłoszenie patentowe „Olej ochronny”.

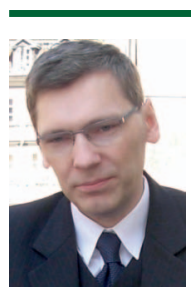

Mgr Jarosław FRYDRYCH

Starszy specjalista

Sieć Badawcza Łukasiewicz - Przemysłowy Instytut Motoryzacji

ul. Jagiellońska 55

03-301 Warszawa

E-mail: jaroslaw.frydrych@pimot.lukasiewicz.gov.pl

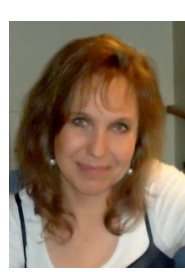

Mgr Monika ZIÓŁKOWSKA

Starszy specjalista

Sieć Badawcza Łukasiewicz - Przemysłowy Instytut

Motoryzacji

ul. Jagiellońska 55

03-301 Warszawa

E-mail:m.ziolkowska@pimot.eu 